\title{
The US, China and the G-77 in the era of responsive patentability
}

\author{
Peter Drahos* \\ Centre for Commercial Law Studies, Queen Mary, University of London, UK and Regulatory Institutions \\ Network, Australian National University
}

The paper argues that China is building its capacity to grant, use and enforce patents. The same is true of Brazil and India. China has the greatest potential of scale of any developing country to use the patent system as a wealth-maximizing tool. The paper considers three questions. Can China make the patent system work for it? If so, how will the US respond? What should the weaker members of the G-77 do in light of the fact that the leaders of the G-77 are no longer interested in dealing with the structural disadvantages that the patent system perpetuates?

Keywords: China, G-77, global value chains, international trade, patent system, US

\section{INTRODUCTION}

The twenty-first century looms as the century of responsive patentability. Responsiveness serves as an important democratic and regulatory ideal when it is used to build institutions that respond to the needs and problems of citizens. ${ }^{1}$ But when the institutions of the state become selectively responsive only to the needs of elites and powerful interest groups then responsiveness breeds a regulatory order that fails the people.

The patent system continues to evolve as a system that is selectively responsive to the wants and goals of powerful business interests, to the point where some question whether it actually encourages innovation. ${ }^{2}$ Responsive patentability refers to this partial and prejudicial responsiveness of the patent system. Some of the answers to the problems of responsive patentability lie in responsive patent regulation, although there are structural limits to how responsive the patent system can be to the preferences of poor people. The purpose of this paper is not, however, to show how the theory of responsive regulation might be applied to the patent system. This has been done elsewhere. ${ }^{3}$ Rather the paper argues that China is embracing the patent system and perhaps responsive patentability. The same is true of Brazil and India, two countries that

* My thanks go to Marc Mimler, the General Editor, for his patience and encouragement as well as an anonymous referee for his or her constructive criticisms. I have done my best to answer them.

1. For a discussion of responsiveness as an ideal see John Braithwaite, 'Responsive Regulation and Developing Economies' (2006) 34 World Development 884.

2. See, eg, Michele Boldrin and David K Levine, Against Intellectual Monopoly (Cambridge University Press, New York 2008); Adam B Jaffe and Josh Lerner, Innovation and Its Discontents (Princeton University Press, Princeton 2004).

3. Peter Drahos, 'An Obligation to Society: Responsive Regulation and the Patent Office' (March 2012) Gazette: European Patent Office Staff Magazine, 36; Peter Drahos, The Global Governance of 
historically have led the charge against the patent system. The great danger is that in these countries where we should have responsive patent regulation serving the people's social welfare we will have, just as in developed countries, responsive patentability that enriches business elites, harms innovation and further deepens the problems of access to welfare-enhancing technologies.

Today's developing states still mount objections to the patent system and to intellectual property rights more broadly. One clear example of this is Argentina and Brazil's initiative in 2004 that eventually resulted in the adoption by the World Intellectual Property Organization in 2007 of a 'Development Agenda' ${ }^{4}$ But with this and similar examples such as the Doha Declaration on the TRIPS Agreement and Public Health (Doha Declaration) one has to be careful to distinguish between negotiating victories that a coalition of states might achieve and what individual states actually do in terms of their domestic regulation of intellectual property. ${ }^{5}$ From the perspective of economic growth it is the latter that matters. It is true that the phenomenal rise of the BRIC (Brazil, Russia, India, China) economies has rendered global governance more polycentric, opening up coalitional and networked possibilities to contest US and EU power. But this polycentricity of global governance has not translated into a bold experimentalism with the patent system. Non-state actors have contributed to the creation of political discourses to contest the ideological hegemony of patent rights and these discourses are useful negotiating assets for developing countries when it comes to framing issues. ${ }^{6}$ But at the level of state institutional regulation, the level which counts, the BRIC economies have accepted the patent system and now spend their time in narcoleptic discussions over matters such as the right level of inventive step, the merits of post-grant opposition, and the scope of an experimental use defence. It may be that the patent system will emerge with new global governors. Whatever the fate of Pax Americana this century, the patent system appears to be an entrenched system of rules by which all those who would be kings in the global economy will have to play.

If the claim that the lead developing countries have largely abandoned any significant opposition to the patent system is right then it does raise other questions. How will developing country powers such as China and India make the patent system work for them? The patent system, it needs to be remembered, is the visible boot of monopoly in the competitive market. It is generally inadvisable for governments to sit back and let these patent boots march through their economies without some restrictions. The patent system, like the tax system, demands constant monitoring and adjustment. Another question is what might happen if China, in particular, is too successful in making the patent system work? What if China is able to obtain patent ownership of

Knowledge: Patent Offices and their Clients (Cambridge University Press, Cambridge 2010), chs 11 and 12; John Braithwaite, Regulatory Capitalism: How it Works, Ideas for Making it Work Better (Edward Elgar, Cheltenham, UK and Northampton, MA, USA 2008), ch 5.

4. For a full discussion of the agenda see the collection of essays in Jeremy de Beer (ed), Implementing the World Intellectual Property Organization's Development Agenda (Wilfrid Laurier Press Waterloo, ON 2009).

5. For an analysis of the Doha Declaration that argues it was a negotiating rather than economic victory, see Peter Drahos, 'Four Lessons for Developing Countries from the Trade Negotiations over Access to Medicines' (2007) 28 Liverpool Law Review 11.

6. Discussions of these discourses are to be found in Gaëlle Krikorian and Amy Kapczynski (eds), Access to Knowledge in the Age of Intellectual Property (MIT Press, Cambridge, MA 2010); Sebastian Haunss and Kenneth C Shadlen (eds), Politics of Intellectual Property: Contestation over the Ownership, Use, and Control of Knowledge and Information (Edward Elgar, Cheltenham, UK and Northampton, MA, USA 2009). 
many more lucrative technologies than it currently has and is able to extract much more in the way of patent rents from the global economy?

Another set of issues relates to developing countries that have very little prospect of being able to make gains from the system. The Group of 77 (G-77) countries, which was formed in 1964 and now has a membership of 132, has many of the poorest countries of the world as members. ${ }^{7}$ Fidel Castro in a speech at a G-77 Summit in Havana in 2000 claimed that developed countries 'control 97\% of the patents the world over and receive over $90 \%$ of the international licenses' rights'. He went on to observe that the "new medications, the best seeds and, in general, the best technologies have become commodities whose prices only the rich countries can afford' ${ }^{8}$ Castro finished with a strong appeal for unity and cooperation amongst the G-77. A politician of his longevity and survival skills must have known that something like an inverse unity rule applies in political life - the stronger the appeal for unity by a politician the less actual unity is present. And so it is in the case of the G-77 and patents. Brazil and India have for all practical purposes abandoned their historical leadership of the G-77 in fighting the neo-regulatory expansion of monopoly privileges in the world trading order. Of course Brazil and India's eloquent diplomats do not announce this in Geneva meetings. They keep up the rhetoric about the injustice of the system, the need for technology transfer, their exclusion from scientific knowledge etc., etc., etc. But these countries have, as the next section will show, joined the ranks of the patent faithful. What then should the weaker members of the G-77 do when it comes to fighting the kinds of price and access problems mentioned by Castro? In a world where they find themselves isolated in rooms of bilateral trade dealing, the answer is far from obvious.

Summing up, the paper argues that the leaders of the G-77 have abandoned their attempts at deep reform of the patent system to meet the development objectives of all G-77 countries. The next section briefly describes the rise and rise of responsive patentability and the high water mark of opposition to it by developing countries and their subsequent surrender. This in turn raises three questions, to each of which the paper sketches an answer. Can China, which probably has the best chance, make the system work for it? If China can do so, what is likely to be the response of the US? What should the weaker members of the G-77 do in light of the fact that the leaders of the G-77 are no longer interested in dealing with the structural disadvantages that the system perpetuates?

\section{PATENTS UPON THE ROAD TO DAMASCUS}

In hindsight, the nineteenth century was one of remarkable experimentation with the patent institution. Some European developing states chose a development path that did not rely on the patent system for innovation. Holland suspended the operation of its patent law of 1817 in $1869 .{ }^{9}$ Eventually it passed a new patent law in 1910 that came into operation in 1912. Switzerland resisted introducing a patent law until 1888. This 1888 law was drafted in ways to make life difficult for patent applicants,

7. The full list of members is available at <http://www.g77.org/doc/members.html>. Many least-developed countries are members of the G-77.

8. The text of Castro's speech is available at $<\mathrm{http}: / / \mathrm{www} . \mathrm{g} 77 . \mathrm{org} / \mathrm{summit} / \mathrm{ceniai} . \mathrm{inf} . \mathrm{cu} /$ f120400i.html>.

9. G Doorman, 'Patent Law in the Netherlands, Part I' (1948) 30 Journal of the Patent Office Society 225 . 
especially in the chemical sector. ${ }^{10}$ Where states had patent law its operational effects were muted by high fees and enforcement problems. In the UK, the first state to convert to industrial capitalism, patent fees were so high for most of the nineteenth century that Boehm and Silbertson suggest that the first 82 years of the century were 'the age of patentless invention'. ${ }^{11}$ There were fierce debates in most European countries about the usefulness and future of the system. ${ }^{12}$ There was also experimentation early on in the century with prizes as an alternative to patents. ${ }^{13}$ All in all, the European developing countries of the time took full advantage of the possibility of institutional experimentation that was available to them because there were no agreements such as the World Trade Organization's Agreement on Trade-Related Aspects of Intellectual Property Rights (1994) (TRIPS) to constrain that possibility.

Two other things happened towards the end of the nineteenth century that are important for present purposes. One was the completion of what was to become the foundation for an international patent framework in the form of the Paris Convention for the Protection of Industrial Property (Paris Convention) in 1883, and the other was the emergence of the modern multinational enterprise. The legal invention of the security in the seventeenth century as an instrument of ownership, when combined with the older legal form of the corporation, allowed for the emergence of the joint stock company. ${ }^{14}$ With their ability to pool vast amounts of capital and transform economic production, these companies entered the domestic and international regulatory systems of states. No other type of actor in the twentieth century would exercise more influence on the evolution of intellectual property standards. ${ }^{15}$

The twentieth century was a time of consolidation, expansion and, in the last quarter of the century, the globalization of the patent system through the trade regime. The details of this story are well beyond the scope of this paper. The systematic use by multinationals of patents to cover fields of invention, which had begun in Germany in the chemical sector, spread to other countries such as the UK and the US and to other technology sectors such as electrical products. ${ }^{16}$ Multinationals in these countries invested heavily in developing in-house laboratories and in-house patenting strategies that had both offensive and defensive dimensions. Patents became important to the maintenance of international cartels, with only US antitrust authorities at various times during the century offering much countervailing regulation. ${ }^{17}$

10. Eric Schiff, Industrialization without National Patents 93 (Princeton University Press, Princeton 1971).

11. Klaus Boehm with Aubrey Silbertson, The British Patent System, volume 1 (Cambridge University Press, Cambridge 1967), 37.

12. Fritz Machlup and Edith Penrose, 'The Patent Controversy in the Nineteenth Century' (1950) 10 Journal of Economic History 1.

13. M Coulter, Property in Ideas: The Patent Question in Mid-Victorian Britain (Thomas Jefferson University Press, Kirkshill, MO 1991) 121.

14. John Braithwaite and Peter Drahos, Global Business Regulation (Cambridge University Press, Cambridge 2000) 143.

15. For the history see Peter Drahos with John Braithwaite, Information Feudalism: Who Owns The Knowledge Economy? (Earthscan, London 2002).

16. On the use of patents by the German chemical industry see Graham Dutfield, Intellectual Property Rights and the Life Science Industries: A Twentieth Century History (Ashgate, Aldershot 2003). See also Luigi Palombi, Gene Cartels: Biotech Patents in the Age of Free Trade (Edward Elgar, Cheltenham, UK and Northampton, MA, USA 2009).

17. Peter Drahos with John Braithwaite, Information Feudalism: Who Owns The Knowledge Economy? (Earthscan, London 2002) 54-55. 
As new scientific and technological developments occurred, adjustments were made to allow these developments to fall within the scope of patentability (examples include the emergence of Markush claims in the 1920s to deal with aspects of chemical patenting, the patentability of software and the isolation doctrine allowing for the patentability of biological discoveries). Patent offices grew dramatically in size and in the second half of the century began to cooperate in various ways leading to a global network of patent administration. ${ }^{18}$ This century also produced a network of multilateral and regional patent agreements. Developing countries were integrated into the international patent framework, often as colonies in the first half of the twentieth century and then through the trade regime beginning with TRIPS and the free trade agreements that followed TRIPS. ${ }^{19}$

The period of greatest resistance by developing countries to the expansion of the patent system came during the 1970s in which they pushed for the formation of a New International Economic Order (NIEO). ${ }^{20}$ During the 1960 s dependency theorists such as Raul Prebisch developed an analysis of how the core countries of the industrial North had a permanent structural advantage over countries of the peripheral South. ${ }^{21}$ This dependency analysis came to be influential within the United Nations Conference on Trade and Development and it helped to shape the negotiating goals of the G-77. At its first ministerial meeting in 1967, the G-77 outlined a programme of action in the Charter of Algiers that included the use of developed country patents on 'the best possible terms' and the elimination of price-fixing and restrictive market supply practices by multinationals using patent licences. ${ }^{22}$ Developing countries had concluded that the rules of the international patent game were stacked against them and the time had come to change those rules and to regulate the behaviour of multinationals in the global economy much more closely. Under the flag of the NIEO they set sail for revisions to the Paris Convention and the adoption of an international code to regulate technology transfer, as well as a code to control restrictive business practices. India and Brazil were not the only countries in the G-77 active on these issues but their leadership was the most consistently important. ${ }^{23}$ Both countries were also crucial players in the group of countries that were opposed to the inclusion of intellectual property rights in the Uruguay Round of Multilateral Trade Negotiations. ${ }^{24}$

TRIPS came into operation in 1995. Developing countries had not been able to prevent its inclusion in the Uruguay Round. Their attempts to revise the Paris Convention to inject more flexibility into the use of compulsory licences also failed. The anger over TRIPS was the most vocal in India, with those who had been deeply involved with the G-77 agenda arguing that TRIPS was aimed at preventing developing countries

18. Peter Drahos, The Global Governance of Knowledge: Patent Offices and their Clients (Cambridge University Press, Cambridge 2010).

19. Peter Drahos, 'BITS and BIPS: Bilateralism in Intellectual Property' (2001) 4 Journal of World Intellectual Property 791.

20. For the history see Susan Sell, Power and Ideas: North-South Politics of Intellectual Property and Antitrust (Sate University of New York Press, New York 1998).

21. Donatella Alessandrini, Developing Countries and the Multilateral Trade Regime: The Failure and Promise of the WTO's Development Mission (Hart Publishing, Oxford 2010) 51-5. 22. See First Ministerial Meeting of the Group of 77: Charter of Algiers, Algeria 10-25 October 1967, Part 2, E, para 7, available at <http://www.g77.org/doc/algier 1.htm>.

23. For a detailed account of their leadership see Susan K Sell, Power and Ideas: North-South Politics of Intellectual Property and Antitrust (Sate University of New York Press, New York 1998) 21. 24. Peter Drahos with John Braithwaite, Information Feudalism: Who Owns The Knowledge Economy? (Earthscan, London 2002) 133. 
from matching the technological development of Western powers. ${ }^{25}$ Much more was in store for developing countries in the form of TRIPS-plus free trade agreements.

The twentieth century also saw the start and end of the globalization of a regulatory alternative to the patent system. Communism, capitalism's great ideological opponent, devised an alternative in the form of the inventor's certificate. It was signed into law by Lenin in $1919 .{ }^{26}$ Under this system inventions become automatically available for use by others but the inventor has the right to remuneration. It is, in other words, a form of liability rule system. The system did spread to other communist states, including China. ${ }^{27}$ It is no longer a flourishing model. It was abolished by Russia in $1991 .^{28}$

There were, of course, many twists and turns in the evolution of the patent system during the course of the twentieth century, but standing back from the detail one can see that the system expanded in terms of scope of patentable subject matter and globalized in terms of spreading as an institution to the territories of states. Attempts by developing countries to modify the international framework to meet their development objectives failed.

These days the ideas of the NIEO emerge as echoes of the past in the rhetorical language of developing country negotiators when the topic of technology transfer is discussed. So, for example, in the climate change negotiations, China and the G-77 continue to argue that privately-patented technologies have to be made available to developing countries on an affordable basis. ${ }^{29}$ They emphasize their right to use compulsory licences as a way of accessing technology. ${ }^{30}$ When China has four of the five largest solar cell manufacturers in the world and these manufacturers are growing because of production innovation rather than cheap labour costs, one wonders how credible these negotiating positions seem to US and EU negotiators. ${ }^{31}$ However, Chinese negotiators only have to point to OECD patent data that shows that Brazil, Russia, India and China between them have only 6.5 per cent of the renewable energy patents so far granted to reinforce their view that they remain locked out of the world's most important technologies. ${ }^{32}$ In the world of international negotiation, rhetoric is cheap and easy to generate, and selection bias when it comes to data is not so much a risk, as inevitable.

Whatever China, India and Brazil say about the patent system in international fora, domestically each country is creating a patent office infrastructure that will allow for

25. See Muchkund Dubey, An Unequal Treaty: World Trading Order After GATT (New Age International, New Delhi 1996). Dubey was a former Chairman of the G-77.

26. WA Van Caenegem, 'Inventions in Russia: From Public Good to Private Property' (1993) 4 Australian Intellectual Property Journal 232.

27. See JW Baxter, World Patent Law and Practice (2nd edn, Lexis Nexis Matthew Bender, New York 1978) 14.

28. WA Van Caenegem, 'Inventions in Russia: From Public Good to Private Property' (1993) 4 Australian Intellectual Property Journal 232, 233.

29. See 'Proposal by the G77 \& China for a Technology Mechanism under the UNFCCC', available at $<$ http://unfccc.int/files/meetings/ad_hoc_working_groups/lca/application/pdf/ technology_proposal_g77_8.pdf>.

30. See 'Joint Submission by African Group, Argentina, Brazil, China, India, Iran, Lebanon, Malaysia, Philippines, Thailand and Uruguay on SHARED VISION', available at <http:// unfccc.int/files/meetings/ad_hoc_working_groups/lca/application/pdf/joint_submission_on_ shared_vision_june_16_2011.pdf>.

31. See 'Chinese Solar Companies Thrive on Manufacturing Innovation', 6 July 2011, available at $<$ http://www.technologyreview.com/business/37954/>.

32. OECD, Compendium of Patent Statistics (OECD, Paris 2008) 21. 
the smooth granting of patents in their territories. ${ }^{33}$ The scale of the investment by all three countries is large, especially in China. The State Intellectual Property Office (SIPO) of China has some 6,000 people working on patent examination. ${ }^{34}$ In terms of the number of applications it is the second largest office in the world. ${ }^{35}$ As part of its twelfth five-year plan China has set itself a very ambitious goal in terms of domestic patents. It is aiming for 3.3 invention patents for every 10,000 head of population by $2015 .{ }^{36}$ India and Brazil have much smaller offices in terms of examination capacity and applications, but like China both are investing in building this capacity. ${ }^{37}$ These two offices are amongst the fastest growing offices in the world. ${ }^{38}$

Whatever these three countries say about the patent system when they are wearing their G-77 hats, an examination of what they are doing domestically to improve their system of patent administration suggests that they see the patent system as crucial to their future plans. Certainly, the volume of patents in the world will continue to increase. For example, if China hits the number of invention patents it is aiming at under its current five-year plan, Chinese residents alone will be generating more than 400,000 patents in the Chinese market by 2015. To keep this in perspective, over roughly the last 25 year period (from April 1984 to the end of 2009) the total number of granted invention patents in China was 586643 out of the 1935827 applications received. ${ }^{39}$ The next 25 years promises to be rather different in terms of numbers. No doubt Chinese inventors will also be encouraged to patent abroad using the PCT system (which itself has a history of being made easier to use). If we assume that China only achieves 75 per cent of its target and India achieves only one third of what China is planning, it points to a future in which rather large and complex constellations of patents will orbit the global economy.

\section{POTS OF GOLD AT THE END OF RAINBOWS}

The World Intellectual Property Organization's leprechauns, whether prompted or not, will say that pots of gold await those who find the end of the patent rainbow. Rainbows are an optical illusion. A lot of time can be wasted on the task of trying to find the end of one. There is scepticism about the social value of the patent system. Boldrin and Levine, for example, conclude that the evidence shows that Machlup was wrong in suggesting it would be irresponsible to recommend the abolition of the patent system - the only socially responsible thing to do is to get rid of it. ${ }^{40}$ Machlup followed up that oft quoted

33. For the details see Peter Drahos, The Global Governance of Knowledge: Patent Offices and their Clients (Cambridge University Press, Cambridge 2010).

34. This figure was provided to me by SIPO officials at a meeting on 21 April 2011. In 2007 SIPO reported that it had about 2700 examiners. See Peter Drahos, The Global Governance of Knowledge: Patent Offices and their Clients (Cambridge University Press, Cambridge 2010) 235. SIPO's latest annual report states that it has recruited 1671 people to deal with examination and a further 2168 to assist with examination. In short, it is building a very large examination workforce. See SIPO Annual Report 2010, 36, available at <http://english.sipo.gov.cn/laws/ annualreports/2010/>.

35. See WIPO, World Intellectual Property Indicators 2011, 40.

36. See <http://english.sipo.gov.cn/news/official/201103/t20110324_590922.html>.

37. In terms of applications the Indian patent office is 9th and the Brazilian office is 12th. See WIPO, World Intellectual Property Indicators 2010, 40.

38. See WIPO, World Intellectual Property Indicators 2011, 40.

39. SIPO, Annual Patent Year Book 1 (2009).

40. Michele Boldrin and David K Levine, Against Intellectual Monopoly (Cambridge University Press, New York 2008) 243. 
recommendation with a qualification: 'This last statement refers to a country such as the United States of America - not to a small country and not a predominantly nonindustrial country, where a different weight of argument might well suggest another conclusion' ${ }^{41}$ In other words, Machlup had little doubt that the patent system did not serve small semiindustrialized countries. Whether there is much that such countries can do about the system in today's world is a question we leave for the next section. The question for this section is whether China can make the patent system work in its favour. It is a large and predominantly industrial country. More than any other developing country it has the scale that is needed to unlock the power of the patent jinnee.

Making the patent system work does not refer to a criterion of welfare efficiency or to a criterion produced through an analysis of the ethics of the system. Rather it refers to a criterion of wealth maximization. Under this criterion the system can be said to work if one country is able to use it to extract monopoly rents from other countries, thereby making it an overwhelming net winner from the system. For example, estimates of net patent rents based on a full application of TRIPS show that the US was by far the biggest winner. ${ }^{42}$

There is also a strong likelihood that the trade data masks the extent to which the US is gaining from the patent system. Trade data reporting assumes production networks within countries producing final products that are then traded across borders. ${ }^{43}$ Obviously this does not square with the reality of today's global economy in which multinationals operate complex supply and production networks that stretch across a number of countries and have intra- and inter-firm characteristics. ${ }^{44}$ In these networks China often ends up being the final assembly point for a product, the parts of which will have come from other countries that make up the links in a global chain of production. ${ }^{45}$ An information technology product that is exported from China to the US may from a trade data perspective appear to contribute to a China-US trade imbalance in China's favour. However, the information technology product and its parts will be covered by a bundle of intellectual property rights. Companies like Apple, IBM and Intel use this bundle of ownership rights to capture the lion's share of value generated by the global production networks that lie behind their final products. ${ }^{46}$ China's share is commensurate with it being the world's factory rather than the world's innovator, a position that Chinese leaders are keen to change. For example, Kraemer, Linden and

41. Fritz Machlup, An Economic Review of the Patent System, Study of the Subcommittee on Patents, Trademarks, and Copyrights of The Committee on the Judiciary (US Government Printing Office, Washington, DC 1958) 80.

42. See World Bank, Global Economic Prospects and the Developing Countries (World Bank, Washington, DC 2002) 133 and 148.

43. Prema-chandra Athukorala and Nokaki Yamashita, 'Global Production Sharing and Sino-US Trade Relations' (2009) 17 China \& World Economy 39, 40.

44. John H Dunning and Sarianna M Lundan, Multinational Enterprises and the Global Economy (2nd edn, Edward Elgar, Cheltenham, UK and Northampton, MA, USA 2008) 489-90. The World Trade Organization has also recognized that global value chains have made traditional trade statistics unreliable. See the comments by Mr Andreas Maurer, Chief of WTO International Trade Statistics Section at <http://www.wto.org/english/res_e/statis_e/miwi_e/background_ paper_e.htm>.

45. Prema-chandra Athukorala and Nokaki Yamashita, 'Global Production Sharing and Sino-US Trade Relations' (2009) 17 China \& World Economy 39, 41.

46. For an analysis of who benefits from these global value chains see Jason Dedrick, Kenneth L. Kraemer and Greg Linden, 'Who Profits from Innovation in Global Value Chains? A Study of the iPod and Notebook PCs' (2010) 19 Industrial and Corporate Change 81. 
Dedrick estimate that ' $\$ 10$ or less in direct labor wages that go into an iPhone or iPad is paid to China workers', the upshot being that China captures only a fraction of the global value chain for these products. ${ }^{47}$

In short, the true benefits to the US of having, at least for the time being, multinationals located within its borders with high levels of ownership of patents and other intellectual property rights, especially trade marks, are very likely to be greater than suggested by trade data that is confined to payments for technology goods by one country to another.

China's effort to change from being an assembler of innovative products to an originator does require a patent rent-extraction strategy. One element of this strategy is a large and efficient patent bureaucracy. Aside from a big office, one needs thousands of patent attorneys fervently drafting applications to feed the big office. China has well over 6000 licensed professional agents and plans to reach 10000 by $2015 .{ }^{48}$ Everything points to China being well on the way to building the world's largest patent bureaucracy.

A wealth-maximization strategy based on patents requires a successful innovation system. China's latest five-year plan (2011-15) states that China 'will strive to speed up the construction of an innovation country'. ${ }^{49}$ The US developed its innovation system during the twentieth century and under different circumstances to those facing China today. Access to energy resources and the cost of energy (environmental and monetary) are two obvious examples of these different circumstances. It is also unclear to what extent one can build a national innovation system in a highly networked world. Just as production networks have globalized, so have networks of scientific knowledge production. ${ }^{50}$ During the course of the twentieth century the US invested heavily in the build up of scientific and technical human capital, and after World War II Federal Government R\&D spending skyrocketed. ${ }^{51}$ These are lessons not lost on the Chinese government as it continues to increase its $R \& D$ spending with the goal of reaching 2.5 per cent of GDP by 2020, and invests heavily in the training of science and engineering graduates. ${ }^{52}$ The US also has the world's largest venture capital market, meaning that more high risk ventures promising the next big thing can be put into play. ${ }^{53}$ China's venture capital market has taken off, but it will take time to acquire maturity and independence. ${ }^{54}$ There is also that vague but important residual of entrepreneurial

47. See Kenneth L Kraemer, Greg Linden and Jason Dedrick, 'Capturing Value in Global Networks: Apple's iPad and iPhone' (July 2011) 1, 6 available at <http://pcic.merage.uci.edu/ papers/2011/Value_iPad_iPhone.pdf $>$.

48. Information provided to the author at the China High-Level Forum on Intellectual Property, Beijing, 20 April 2011 by the Secretary General of the All-China Patent Agents Association.

49. Based on a translation prepared by the European Union delegation in China and available at $<$ http://cbi.typepad.com/china_direct/2011/05/chinas-twelfth-five-new-plan-the-full-englishversion.html $>$.

50. See The Royal Society, Knowledge, Networks and Nations: Global Scientific Collaboration in the 21st Century (The Royal Society, London 2011).

51. David C Mowery and Nathan Rosenberg, Paths of Innovation: Technological Change in 20th-Century America (Cambridge University Press, Cambridge 1998) 28.

52. The Royal Society, Knowledge, Networks and Nations: Global Scientific Collaboration in the 21st Century (2011) 19.

53. WIPO, World Intellectual Property Indicators 2010, 17.

54. For a discussion of the problems see Bat Batjargal and Mannie (Manhong) Liu, 'Entrepreneurs' Access to Private Equity in China: The Role of Social Capital' (2004) 15 Organization 
culture when it comes to innovation. Like invisible threads of gossamer it tugs and supports individuals as they bet everything on their ideas. Whether China can emulate this aspect of the US innovation story only time will tell. ${ }^{55}$

For a wealth-maximization strategy based on patents to succeed, a country's innovation system must generate core technologies. China's economic success has its roots in multinational enterprises being prepared to locate their manufacturing facilities within its borders. But the factories that have been set up in China appear not to have come equipped with doors leading to the secrets surrounding the core technologies of foreign multinationals. China's relative lack of ownership of core technologies worries Chinese policy makers and commentators. ${ }^{56}$ So, as one might expect, China's five-year plan makes the building of core technology capability a priority, identifying seven new strategic industry sectors for development: energy conservation and environmental protection, new-generation IT, biotechnology, high-end equipment manufacturing, new energies, new materials, and new energy automobiles. ${ }^{57}$

The rapid creation of a patent bureaucracy by China might be seen as part of a foreign direct investment (FDI) strategy aimed specifically at increasing China's core technology ownership. On one view there is a straightforward link between strengthening intellectual property rights and FDI. Mansfield's study suggested that if a developing country strengthened intellectual property protection it would encourage more FDI from US multinationals. ${ }^{58}$ However, a number of methodological problems have been identified with Mansfield's study. ${ }^{59}$ Amongst other things, the usefulness of his study is limited by the fact that he failed to disaggregate the different types of intellectual property that were relevant to the FDI concerns of companies.

In the case of China it would seem that there is no straightforward link between improving the administration of patents, FDI and obtaining access to core technologies. China has a spectacular record of obtaining FDI (in 2009 it was the second largest recipient of FDI), ${ }^{60}$ a strong record of improving patent administration, but, based on the concerns of its latest five-year plan, a relatively poor record of obtaining access to core technologies. There is also something of a puzzle here since it continues to invest in strengthening its patent administration. However, multinationals do not use the patent system to disclose the vital know-how around their core technologies. If they did, China could rely on foreign patent disclosures to access that know-how. The failure of the patent system as a disclosure system is well known. ${ }^{61}$ Patents are important for extracting value from

Science 159. Venture capital has been important to innovation in the US. See Paul Gompers and Josh Lerner, 'Short-Term America Revisited? Boom and Bust in the Venture Capital Industry and the Impact on Innovation' (2003) 3 Innovation Policy and the Economy 1.

55. There is some scepticism. Eg, see Yasheng Huang, Capitalism with Chinese Characteristics: Entrepreneurship and the State (Cambridge University Press, New York 2008).

56. Handong $\mathrm{Wu}$, 'One Hundred Years of Progress: The Development of the Intellectual Property System in China' (2009) 1 The WIPO Journal 117, 121.

57. See <http://cbi.typepad.com/china_direct/2011/05/chinas-twelfth-five-new-plan-the-fullenglish-version.html $>$.

58. Edwin Mansfield, 'Intellectual Property Protection, Foreign Direct Investment, and Technology Transfer', Discussion Paper 19, World Bank (1994).

59. See Paul J Heald, 'Misreading a Canonical Work: An Analysis of Mansfield's 1994 Study' (2003) 10 Journal of Intellectual Property Law 309.

60. See UNCTAD, World Investment Report 2010: Investing in a Low Carbon Economy (2010) xix.

61. See Peter Drahos, The Global Governance of Knowledge: Patent Offices and their Clients (Cambridge University Press, Cambridge 2010) 27-32. 
global value chains of production, but in terms of protecting innovation, trade secrets are probably much more important. In short, China probably has very little to gain in terms of access to core technologies by continuing to strengthen patent administration.

China is probably unique amongst developing country governments in terms of its bargaining power in dealing with multinationals. It has the lure of access to its large domestic market and a central government that is not politically dominated by ties to multinational capital. ${ }^{62}$ This in turn gives it a better chance of extracting favourable terms in high-technology joint ventures with foreign multinationals. The principal vehicle of cooperation in these joint high-technology ventures are Chinese stateowned enterprises. ${ }^{63}$ One possibility is that the Chinese government is assuming that, with its strategic support, selected state-owned enterprises in key technology sectors will, through their close partnerships with multinational firms, acquire greater capabilities that will lead those enterprises to capture an increasing share of the world's important core technologies. A 2004 study did find evidence of FDI helping to improve Chinese innovation capability, but this capability was primarily expressed by more applications for design rather than invention patents. ${ }^{64}$ The goal for Chinese enterprises is to file for invention patents over core technologies.

Strengthening patent bureaucracy will almost certainly do nothing to enhance the spillover effects of FDI. Foreign multinationals will do their utmost to protect their core technologies by means of secrecy. However, as more and more multinationals are lured into the Chinese market under deals struck with the central government, locating their manufacturing and research facilities in China, the black boxes of secrecy that surround their core technologies will inevitably begin to leak, as employee mobility, reverse engineering, learning by doing and social processes of informal information exchange begin to drill holes into those boxes.

One hypothesis might be that patent administration is being strengthened for the time when China's corporate enterprises need that bureaucracy to play the wealthmaximization game. The Chinese domestic market will be flooded with patents owned by Chinese enterprises. There is some evidence that Chinese patent applicants are going from application to grant more quickly than foreign applicants. ${ }^{65}$ Through a process of learning-by-litigating these enterprises will have become much more skilled at using patents against foreign competition. Foreign multinationals will find themselves having to hurdle many patents to get access to China's domestic market. Given the scale of China's investment in patent administration, it appears that the Chinese government is betting that this will happen sooner rather than later. There certainly will be casualties amongst Chinese firms along the way, since the evidence also shows that the rising level of FDI in China is also bringing in many more foreign patents. ${ }^{66}$ The discipline that the Chinese government is imposing on its firms seems to be one of patent or perish.

62. Alberto Gabriele, 'S\&T Policies and Technical Progress in China's Industry' (2002) 9 Review of International Political Economy 319, 326.

63. Ibid, 319, 338-40.

64. Kui-yin Cheung and Ping Lin, 'Spillover Effects of FDI on Innovation in China: Evidence from the Provincial Data' (2004) 15 China Economic Review, 25.

65. The reasons for this, however, are less clear. See Johannes Liegsalz and Stefan Wagner, 'Patent Examination at the State Intellectual Property Office in China', European School of Management and Technology Working Paper (2011), available at <www.esmt.org>.

66. See Haiyang Zhang, 'What is Behind the Recent Surge in Patenting in China?' (2010) 5 International Journal of Business and Management 83. 
This is a strategy not without risks. European developing countries and the US in the nineteenth century moved gradually from weak to stronger levels of intellectual property protection. This was a non-linear process. For example, in the two decades after World War II the US relaxed its patent regime thereby benefitting a number of high technology industries, especially the microelectronics and computer industries. ${ }^{67}$ No doubt today's Chinese leaders will be keeping Deng Xiaoping's advice in mind: 'boldly try, and if you fail, just correct'.

\section{IF CHINA SUCCEEDS, WHAT THEN?}

In the US, legislators and policy makers worry about the loss of US technological leadership. Testimony to the effect that the end is nigh for the US as the incubator of the world's most important technologies is easy enough to find. ${ }^{68}$ China is depicted as a technological rival with a reputation only marginally better than that of Richard III.

Let us assume for the sake of argument that a succession of five-year plans turn China into a patent superpower with control over many core technologies. How might the US respond to such a situation? One possibility is that it would simply issue compulsory licences over those foreign technologies it believed were vital to its national interests. Over the course of the twentieth century, antitrust law has been intellectual property's constant regulatory shadow. For significant periods of the twentieth century it was a shadow that loomed over intellectual property owners to check the exclusionary uses of their monopoly powers. ${ }^{69}$ There is a resilience to antitrust principles in the US that should never be underestimated. No other country would have done what the US did to AT\&T in the 1970s when it brought an antitrust action against AT\&T, turning it into eight smaller companies (the seven Baby Bell regional companies and a smaller AT\&T as the long distance carrier). ${ }^{70}$ No country has used compulsory licensing of patents on the scale of the US. During the 1940s and 1950s antitrust settlements produced compulsory licences affecting somewhere between 40,000 to 50,000 patents. $^{71}$

It is true that in the US in the 1980s the more aggressive approach to regulating the market power of intellectual property owners based on the assumption of the anticompetitive nature of intellectual property was replaced by one that no longer saw intellectual property as inherently anticompetitive. ${ }^{72}$ That said, antitrust remains an important complementary institution to intellectual property. The twentieth-century history of the

67. See David C Mowery and Nathan Rosenberg, Paths of Innovation: Technological Change in 20th-Century America (Cambridge University Press, Cambridge 1998) 43.

68. China's High Technology Development: Hearings Before the US-China Economic and Security Review Commission, 109th Congress, 21 and 22 April, 2005, available at $<\mathrm{http}: / /$ www.uscc.gov/hearings/2005hearings/transcripts/05_04_21_22.pdf>.

69. Eleanor M Fox, 'Can Antitrust Policy Protect the Global Commons from Excesses of IPRs?' in KE Maskus and JH Reichman (eds), International Public Goods and Transfer of Technology Under a Globalized Intellectual Property Regime (Cambridge University Press, Cambridge 2005) $758,760-61$.

70. John Braithwaite and Peter Drahos, Global Business Regulation (Cambridge University Press, Cambridge 2000) 325.

71. See FM Scherer, 'Antitrust, Efficiency and Progress' (1987) 62 New York University Law Review, 998, 1017.

72. Eleanor M Fox, 'Can Antitrust Policy Protect the Global Commons from Excesses of IPRs?' in KE Maskus and JH Reichman (eds), International Public Goods and Transfer of Technology Under a Globalized Intellectual Property Regime (Cambridge University Press, 
relationship between these two institutions shows how it has been recalibrated according to circumstances. The pragmatism that is implicit in Deng Xiaoping's observation that China should 'wade across the stream by feeling the way' is not a bad characterization of how antitrust and intellectual property have been used to facilitate the evolution of a distinctive US knowledge-based capitalism.

A change in the position of the US on the innovation ladder that is triggered by China's success may prompt another recalibration of the relationship between antitrust and intellectual property. Certainly future Chinese multinationals should not assume that the apparent sanctity with which intellectual property rights are currently held in some quarters in the US will continue once foreign entities come to hold intellectual property levers of ownership over innovation sectors crucial to US interests.

\section{AND WHAT ABOUT POOR STATES?}

The many small predominantly non-industrial members of the G-77 have nothing to gain from the patent system, but if the argument of the second section of this paper is right they can no longer count on China, India and Brazil to help them contest patent monopoly ideology. The unity of the G-77 is only to be found in speech-making.

Poor states are already integrated into a global network of patent governance that allows multinationals to obtain patents in their territories if they so wish. ${ }^{73}$ Their integration into the patent system will continue, the main vehicle of this integration being trade agreements that contain TRIPS-plus standards. This core-periphery process of integration has a history stretching back hundreds of years. ${ }^{74}$

Most citizens in poor states cannot afford to pay patent prices for access to needed medical and food technologies. For example, the least developed countries have per capita incomes of US\$745 or less. ${ }^{75}$ Not much can be afforded on this kind of income. Essentially the citizens of poor states will have to learn to live and die with the patent system. Their future will largely be dependent on the charitable good works of rich country networks made up of foundations, NGOs, companies and wealthy states. Crises of one sort or another in poor countries will affect compassionate individuals who, using their resources and influence, will stitch together charity networks to address particular problems. More poor people with HIV have received access to patented antiretrovirals as a result of these networks than would have done in their absence. The Clinton Foundation, for example, claims on its website that it has helped some two million people gain access to treatment for HIV/AIDS. ${ }^{76}$

Cambridge 2005) 758, 761. For a discussion of the approach in Europe see Gustavo Ghidini, Innovation, Competition and Consumer Welfare in Intellectual Property Law, ch 5 (Edward Elgar, Cheltenham, UK and Northampton, MA, USA 2010).

73. See Peter Drahos, The Global Governance of Knowledge: Patent Offices and their Clients (Cambridge University Press, Cambridge 2010) 47.

74. Ruth Okediji, 'The Limits of Development Strategies at the Intersection of Intellectual Property and Human Rights', in Daniel Gervais (ed), Intellectual Property, Trade and Development: Strategies to Optimize Economic Development in a TRIPS-Plus Era 355, 384 (Oxford University Press, Oxford 2007).

75. Committee for Development Policy and United Nations Department of Economic and Social Affairs, Handbook on the Least Developed Country Category: Inclusion, Graduation and Special Support Measures (United Nations, New York 2008) 39, available at <http:// www.un.org/en/development/desa/policy/cdp/cdp_publications/2008cdphandbook.pdf>.

76. <http://www.clintonfoundation.org/what-we-do/clinton-health-access-initiative>. 
The structural role of the patent system in making knowledge a scarce resource so that the rich can get richer will from time to time come in for some angry denunciation, and some economists will from time to time repeat the not-so-startling conclusion that global monopoly privileges are globally inefficient. However, the patent system, like the poor, will stay with us. Political elites everywhere have become convinced that this winnertake-all system best serves their techno-nationalist and wealth-maximizing ambitions. That is true of elites in China as much as it is elites in the US. China's market socialism may yet evolve into a close variant of US knowledge monopoly capitalism. This ending to China's development story would not surprise readers of Animal Farm.

In the face of this kind of consensus about the virtues of the patent system there is not much that poor countries can do. An individual country can perhaps pray that an alms-giving network coalesces around its problem rather than that of its neighbour.

\section{CONCLUSION}

The evidence suggests that China has well and truly embraced the patent system as part of its development journey. The same can be said of Brazil and India. These leaders of the G-77 can no longer be said to represent the interests of poorer members of the G-77 when it comes to dealing with the problem of global knowledge monopolies in the world trading order. Charity networks are evolving to ameliorate some of the effects of this trading order for some countries.

China is making the kind of investments in R\&D funding and the development of scientific human capital that are needed to make the patent system perform its function of wealth maximization. China's rapid build up of a patent bureaucracy appears to be part of a strategy to fast-track the experience of its enterprises in working in patentintense business environments. Whether encouraging the saturation of its domestic market with patents will produce the desired selection effects is an open question. No other country has, to borrow Deng Xiaoping's metaphor, crossed the stream in this way. If it works we can expect that some time this century Pax Sinica will chug past Pax Americana on the back of global technology monopolies. The US will, in forging a response, draw heavily on antitrust principles and remedies, much as it did in the last century when international cartels threatened its economic interests. 